\title{
STUDI DURASI BELAJAR SERVICE RINGAN ENGINE SEPEDAMOTOR MELALUI METODE PEMBELAJARAN DEMONSTRASI BAGI SISWA TUNARUNGU
}

\author{
Yayu Rahayu', Iwa Kuntadi ${ }^{2}$, Tatang Permana ${ }^{3}$ \\ Departemen Pendidikan Teknik Mesin \\ Universitas Pendidikan Indonesia \\ Jl. Dr. Setiabudhi No. 207 Bandung 40154 \\ rhyayu08@gmail.com
}

\begin{abstract}
ABSTRAK
Penelitian ini bertujuan untuk memodifikasi prilaku dan perubahan prilaku subjek, serta ada atau tidaknya pengaruh intervensi terhadap target behaviordalam fase yang telah ditentukan. Penelitian ini menggunakan metode subjek tunggal. Desain penelitian menggunakan desain reversal tipe A-B-A, dimana pengukuran fase baseline diulang dua kali. Fase baseline (A1) dilakukan sebelum fase intervensi, kemudian dilakukan fase baseline (A2). Fase baseline (A1)dan fase baseline (A2) dilakukan sebanyak empat kali, sedangkan fase intervensi dilakukan sebanyak lima kali. Penelitian dilakukan terhadap anak tunarungu tingkat II di SMA-LB Citeureup Kota Cimahi, berdasarkan hasil penelitian pelaksanaan keterampilan otomotif menggunakan metode demonstrasi mengalami peningkatan, hal tersebut dapat dilihat pada perubahan level yaitu $+2,+3$ untuk keterampilan perawatan saringan udara.
\end{abstract}

Kata kunci: disabilitas, tunarungu, keterampilan, otomotif. perilaku.

\section{PENDAHULUAN}

Lembaga Pendidikan pada umumnya dan sekolah pada khususnya merupakan tumpuan harapan para orang tua, siswa dan warga masyarakat sebagai tempat berlangsungnya proses pendidikan dan memperoleh pengetahuan, sikap, dan keterampilan. Anak atau siswa berkebutuhan khusus memiliki exceptionality (perkecualian) dengan kekhususannya, seperti: tuna netra, tunarungu, tuna grahita, tuna daksa, tuna laras, autis maka dalam pendidikannya siswa berkebutuhan khusus membutuhkan pendidikan khusus. Pendidikan khusus adalah penyelenggaraan pendidikan untuk peserta didik yang berkelainan atau peserta didik yang memiliki kecerdasan luar biasa yang diselenggarakan secara inklusif (bergabung dengan sekolah biasa) atau berupa satuan pendidikan khusus pada tingkat pendidikan dasar dan menengah (Dit. Pembinaan SLB, 2009). Siswa dengan kebutuhan khusus biasanya sekolah di sekolah luar biasa (SLB) atau sekolah umum yang menerima anak berkebutuhan khusus.

Berpedoman pada Peraturan Menteri Pendidikan Nasional Nomor 22 Tahun 2006 mengenai standar isi untuk satuan pendidikan dasar dan menengah yang menjelaskan mengenai struktur kurikulum satuan pendidikan SMA-LB. Pendidikan khusus di Indonesia memiliki kurikulum yang difokuskan pada program khusus, muatan lokal dan pengembangan

\footnotetext{
${ }^{1}$ Mahasiswa Departemen Pendidikan Teknik Mesin FPTK UPI

2 Dosen Departemen Pendidikan Teknik Mesin FPTK UPI

${ }^{3}$ Dosen Departemen Pendidikan Teknik Mesin FPTK UPI
} 
diri. Pembekalan keterampilan di SMA-LB bertujuan untuk membentuk peserta didik yang memiliki kepribadian percaya diri dan dapat hidup mandiri. Sesuai dengan tujuan mata pelajaran keterampilan vokasional yang tertuang dalam kurikulum tahun 2006 tentang standar kompetensi dan kompetensi dasar. Pengajaran keterampilan di SMA-LB di dalam struktur kurikulumnya diberi nama Keterampilan Vokasional atau Teknologi Informasi dan Komunikasi. Nama tersebut merupakan paket keterampilan pilihan yang dapat dipilih sesuai dengan minat dan bakat peserta didik. Pengembangan diri dalam pengajaran keterampilan di SMA-LB memberikan kesempatan kepada siswa untuk mengembangkan dan mengekspresikan diri sesuai dengan kemampuan, bakat, minat serta kebutuhan setiap siswa. Kegiatan pengembangan diri dibimbing oleh guru, konselor atau tenaga kependidikan yang dapat dilakukan dalam bentuk kegiatan ekstrakurikuler.

Mata pelajaran keterampilan di SMA-LB terdiri dari dua aspek yaitu: kerajinan dan teknologi. Aspek kerajinan mencakup sub aspek apresiasi dan kreasi sedangkan dalam aspek teknologi mencakup keterampilan dalam pembuatan produk diantaranya: otomotif dan komputer. Keterampilan dasar otomotif didalamnya terdapat beberapa kompetensi yaitu: cuci kendaraan, pengecatan kendaraan, tune-up ringan, hingga overhaul (Jama, 2008). Kendaraan yang digunakan dalam pembelajaran adalah sepeda motor karena dianggap lebih ringan dan mudah untuk dipelajari oleh siswa berkebutuhan khusus.

Keterampilan otomotif di SMA-LB Citeureup Kota Cimahi merupakan salah satu keterampilan yang diharapkan dapat meningkatkan kompetensi anak dalam bidang otomotif. Berdasarkan observasi awal yang dilakukan peneliti pada pelaksanaan pembelajaran keterampilan otomotif di SMA-LB Citeureup Kota Cimahibelum bisa berjalan dengan optimal. Salah satu pengajar di SMA-LB Citeureup Kota Cimahi mengemukakan beberapa faktor kekurangan dalam pembelajaran keterampilan otomotif: tidak adanya guru keterampilan yang sesuai dengan bidang keterampilan otomotif, komunikasi anak tunarungu yang terbatas merupakan salah satu penyebab kurangnya pemahaman dalam proses pembelajaran, sumber belajar yang terbatas, pemilihan metode pembelajaran yang kurang tepat.

Salah satu akibat dari kurang tepatnya metode yang digunakan menyebabkan siswa di menjadi kurang terampil. Siswa dapat melakukan pembongkaran dan pemasangan namun siswa tunarungu yang melakukan praktik keterampilan tidak mengehetahui atau mengenal dengan tepat nama-nama komponen dan fungsi setiap komponen dengan benar. Pembelajaran keterampilan vokasional teknologi harus memiliki model pembelajaran yang sesuai dengan 
siswa berkebutuhan khusus. Hal tersebut agar siswa dapat memperoleh kompetensi akademik bidang teknologi yang dapat digunakan dalam bekerja secara mandiri di dunia kerja maupun dalam membangun bidang usaha mandiri (Syaodih, 2009).

Metode belajar yang dipakai dapat mempengaruhi hasil belajar siswa, penggunaan metode pembelajaran harus sesuai dengan tujuan pembelajaran yang ingin dicapai, materi pembelajaran, dan kondisi siswa. Komunikas merupakan kendala utama yang dihadapi siswa tunarungu dalam proses pembelajaran, bagi siswa tunarungu prinsip pembelajaran keterampilan otomotif akan lebih efektif melalui bimbingan langsung pada materi yang dipelajarinya.

Pengembangan pembelajaran keterampilan dengan menggunakan metode demonstrasi merupakan salah satu alternatif metode pembelajaran yang dapat digunakan oleh siswa tunarungu. Metode demonstrasi diharapkan bisa menutupi kekurangan siswa tunarungu dalam menangkap informasi pembelajaran yang disampaikan oleh guru karena dalam metode demonstrasi aspek visual dalam praktek dapat dipahami dengan baik oleh siswa sehingga kompetensi yang dimiliki oleh siswa tunarungu bisa lebih efektif. Hubungan metode demonstrasi dengan keefektipan praktik keterampilan untuk siswa tunarungu dapat diukur dengan melihat durasi belajar siswa tersebut (Azis, 2007).

Tujuan penelitian ini yaitu medeskripsikan proses belajar siswa SMA-LB dalam implementasi alternatif metode pembelajaran keterampilan vokasional teknologi otomotif melalui pendekatan pembelajaran latihan keterampilan dan demonstrasi khususnya pada mata pelajaran service ringan sepeda motor; mendeskripsikan ketercapaian waktu rata-rata kompetensi pada siswa tunarungu dalam kompetensi perawatan saringan udara pada sepeda motor; dan mendeskripsikan hasil belajar keterampilan otomotif pada siswa tunarungu dalam kompetensi perawatan saringan udara sepeda motor.

\section{METODE PENELITIAN}

Metode penelitian ini menggunakan metode eksperimen dengan menggunakan single subject research atau pendekatan subjek tunggal. Penelitian ini mengumpulkan data yang diperlukan dengan melihat ada atau tidaknya pengaruh yang terjadi pada subjek dengan perlakuan yang dilakukan secara berulang-ulang dalam waktu tertentu. Desain penelitian hasil pengembangan dari desain penelitian A-B yaitu desain penelitian A-B-A dimana pengukuran fase baseline dilakukan dua kali. Desain subjek tunggal adanya pengukuran target behavior dilakukan secara berulang-ulang dengan periode waktu tertentu. Perbandingan tidak 
dilakukan antar kelompok maupun individu tetapi dibandingkan dalam subjek yang sama dengan kondisi berbeda. Desain A-B-A yang memiliki 2 fase yaitu: A1 (baseline), B (intervensi), dan A2 (baseline).

Data diambil dengan cara observasi partisipatif di mana peneliti terlibat dengan kegiatan sehari-hari orang yang sedang diamati. Peneliti ikut melakukan apa yang dikerjakan oleh sumber data, dan ikut merasakan suka dukanya dengan demikian data yang diperoleh akan lebih lengkap dan tajam. Instrument yang digunakan adalah berupa tes keterampilan. Format tes disusun berdasarkan point-point tentang kejadian atau tingkah laku yang digambarkan akan terjadi dalam proses pemeliharaan saringan udara yang baik dan benar.

\section{HASIL PENELITIAN}

Hasil penelitian diperoleh melalui pengamatan dan observasi langsung selama proses pembelajaran keterampilan perawatan saringan udara pada siswa tuna rungu. Waktu pengamatan berlangsung selama 14 fase dengan fase baseline (A1) dilakukan sebanyak empat kali dengan kondisi siswa belum sama sekali mendapatkan intervensi atau perlakuan, fase intervensi (B) dilakukan sebanyak lima kali dengan cara memberikan intervensi atau perlakuakn kepada siswa untuk mengubah target behavior siswa dan kemudian fase baseline (A2) dilakukan sebanyak 4 kali setelah adanya intervensi kepada siswa. Data hasil pengamatan yang didapatkan pada fase A1, B, dan A2 merupakan data mentah yang perlu diolah kembali dengan teknik analisis data.

Kegiatan awal pada proses pembelajaran dilakukan guru dengan masuk ke dalam ruang kelas kemudian mengucapkan salam pembuka, mengarahkan siswa untuk berdoa, mengecek daftar hadir siswa, menjelaskan tujuan pembelajaran yang diharapkan dapat dicapai siswa dan memotivasi siswa agar semangat dalam proses pembelajaran. Kegiatan awal ini diharapkan dapat menambah minat siswa untuk melaksakan proses belajar keterampilan perawatan saringan udara pada sepeda motor nanti.

Guru menjelaskan fungsi alat-alat yang akan digunakan dalam perawatan saringan udara sepeda motor dengan mempraktikan langsung kepada siswa seperti penjelasan cara menggunakan obeng, pemasangan air gun serta fungsinya. Siswa akan memahami alat-alat yang akan digunakan sehingga tidak terjadi kesalahan dalam pemilihan dan penggunaan alat praktik. Guru menjelaskan alat-alat yang digunakan, mempraktikan cara penggunaan alat-alat yang akan digunakan, menjelaskan cara penggunaan dan pengaplikasian alat yang digunakan 
dalam praktek membersihkan saringan udara, meminta siswa untuk mencoba menggunakan alat-alat yang akan digunakan, mempraktikan langkah-langkah perawatan saringan udara pada sepeda motor. Sisswa mempraktikan kembali langkah kerja yang telah dilakukan oleh guru dengan arahan dan pengawasan dari guru.

Guru menyimpulkan materi setelah selesai proses pembelajaran kemudian menginformasikan kepada siswa meteri selanjutnya masih mengulang materi yang telah diajarkan. Proses pembelajaran ditutup dengan berdoa lalu salam penutup oleh guru. Langkah kerja perawatan saringan udara terdiri dari tujuh bagian langkah kerja utama yaitu dimulai dari beberapa indikator: persiapan kerja, persiapan alat dan bahan, proses kerja melepas saringan udara dari sepeda motor, proses kerja membersihkan saringan udara, dan proses kerja memasangkan saringan udara pada sepeda motor.

Analisis dalam kondisi kemampuan keterampilan perawatan saringan udara pada penelitian ini terdiri dari empat kondisi fase baseline (A1), lima kondisi fase intervensi (B) dan 4 kondisi fase baseline (A2). Analisis dalam kondisi meliputi: panjang kondisi; estimasi kecenderungan arah; kecenderungan stabilitas; jejak data; level stabilitas dan rentang; level perubahan; dan rangkuman hasil analisis dalam kondisi.

\section{PEMBAHASAN}

Semua siswa memiliki estimasi kecenderungan yang berubah mulai dari fase baseline A1 sebelum dilakukan intervensi kemampuan perawatan saringan udara siswa satu dan siswa dua mendatar. Estimasi kecenderungan arah pada fase intervensi B memiliki kecenderungan arah meningkat. Begitu juga pada fase baseline A2 setelah dilakukannya intervensi menggambarkan kecenderungan meningkat. Stabilitas data pada kemampuan keterampilan perawatan saringan udara kedua siswa menunjukan arah positif (+). Artinya perubahan kemampuan keterampilan yang dimiliki siswa mengarah pada arah positif atau membaik (Suryosubroto, 2002). Perubahan level yang meningkat menggambarkan bahwa penggunaan metode demonstrasi dalam proses belajar perawatan saringan udara memiliki pengaruh baik atau positif.

Hasil analisis antar kondisi ditunjukan dengan data overlap yang membandingkan data fase baseline A1 sebelum dilakukan intervensi dengan fase intervensi B menunjukan nilai data terendah adalah $20 \%$. Artinya semakin kecil nilai overlap brarti intervensi yang telah dilakukan berpengaruh terhadap target behavior berupa kemampuan keterampilan perawatan saringan udara sepeda motor pada siswa. 
Intervensi yang telah diberikan pada siswa berupa pembelajaran keterampilan otomotif menggunakan metode demonstrasi berdampak positif atau baik terhadap perilaku siswa. Penggunaan metode demonstrasi pada anak tuna rungu dirasa sangat tepat. Siswa tuna rungu memiliki keterbatasan dalam berkomunikasi dan metode demonstrasi memudahkan siswa memahami materi pembelajaran melalui praktik langsung pada sepeda motor (Slameto, 2013).

Analisis durasi belajar keterampilan menghasilkan data ketercapaian waktu bidang keahlian perawatan saringan udara sepeda motor pada siswa didik tunarungu pada setiap fase mengalami peningkatan. Perubahan rata-rata ketercapaian waktu pada praktik perawatan saringan udara yang dilaksanakan siswa menunjukan rata-rata peningkatan yang stabil dari fase baseline (A1), ke fase baseline (A2). Rata-rata ketercapaian waktu proses kerja untuk siswa 1 adalah sebesar 12,23 menit dan 11,12 menit pada siswa 2. Kemudian data tersebut apabila dibandingkan dengan waktu rata-rata normal perawatan saringan udara yaitu selama 12 menit. Ketercapaian waktu siswa tunarungu dalam bidang keahlian perawatan saringan udara tidak jauh berbeda dengan orang normal. Siswa tunarungu dalam pembelajarannya hanya terkendala pada aspek komunikasi atau penangkapan informasi namun dalam pelaksanaan praktik tidak jauh berbeda (Efendi, 2008).

\section{KESIMPULAN}

Kesimpulan penelitian ini, sebagai berikut: proses belajar siswa SMA-LB dalam implementasi alternative model pembelajaran keterampilan vokasional teknologi otomotif melalui pendekatan pembelajaran latihan keterampilan dengan demonstrasi memiliki kecenderungan perkembangan yang meningkat setiap fasenya. Siswa dalam proses belajar lebih dapat memahami materi yang diharapkan dapat tercapai dan hasil belajar siswa dalam pembelajaran. Ketercapaian waktu bidang keahlian perawatan saringan udara sepeda motor pada siswa didik tunarungu pada setiap fase-nya mengalami peningkatan. Perubahan rata-rata ketercapaian waktu pada praktik perawatan saringan udara yang dilaksanakan siswa menunjukan rata-rata peningkatan yang stabil. Hasil belajar bidang keahlian perawatan saringan udara pada siswa tunarungu dengan menggunakan metode demonstrasi mengalami peningkatan setiap fase-nya.

\section{DAFTAR PUSTAKA}

Azis, A. (2007). Metode dan Model-Model Mengajar. Bandung: Alfabeta. 
Direktorat Pembinaan Sekolah Luar Biasa. (2009). Pendidikan Khusus dan Pendidikan Layanan Khusus. Jakarta.

Efendi, M. (2008). Pengantar Psikopedagogik Anak Berkelainan. Jakarta: PT. Bumi Aksara.

Jama, J. (2008). Teknik sepeda motor jilid 2 untuk SMK. Jakarta: Departemen Pendidikan Nasional.

Suryosubroto, B. (2002). Beberapa aspek dasar-dasar kependidikan. Jakarta: PT. Rineka Cipta.

Slameto. (2013). Belajar dan faktor-faktor yang mempengaruhinya. Jakarta: Rineka Cipta.

Syaodih, N. (2009). Landasan Psikologi Proses Pendidikan. Bandung: PT.Remaja Rosdakarya. 